\title{
Managerial Opportunism: Monitoring Financial Risk of Malaysian Shariah-compliant Companies
}

\author{
Aziatul Waznah Ghazali (Corresponding author) \\ Kingston Business School, Kingston University London, Kingston Hill campus \\ Kingston Hill, Kingston Upon Thames, KT2 7LB, London \\ Tel: +6012-5123271 E-mail: aziatul.ghazali@gmail.com
}

\author{
Mohd Taufik Mohd Suffian \\ Faculty of Accountancy \& Accounting Research Institute (ARI), Universiti Teknologi MARA \\ Perak, 40450 Shah Alam, Selangor, Malaysia \\ Tel: +603-55442402 E-mail: taufiksuffian@gmail.com \\ Zuraidah Mohd Sanusi \\ Accounting Research Institute (ARI), Universiti Teknologi MARA, 40450 Shah Alam, \\ Selangor, Malaysia \\ Tel: +6013-55442402 E-mail: zuraidahms@gmail.com \\ Fahdah Sultan Alsudairi \\ Faculty of Economics \& Administration, King Abdul Aziz University, 2907 Muhamadia- \\ Jeddah, 23623-9073, Saudi Arabia \\ Tel: +966-556669937 E-mail: falsudairi@kau.edu.sa
}

\begin{abstract}
Managerial opportunism, such as earnings management, is a rampant, but often discreet, among certain managers. Agency theory and the notion of conflict of interest are used as bases to assume that managers would resolve to engage with inappropriate activities for their personal benefits. Distortion of earnings would erode investor confidence and is detrimental to the capital market. The Islamic capital market with Shariah-compliant firms is expected not to engage in activities that go against the religion code of conduct. The main purpose of this study is to investigate managerial opportunism among Shariah-compliant companies, specifically the relationship between real earnings management and the risk of financial distress, leverage, and free cash flow. This study employs 4,115 data from 694 sample companies for five years (2009-2013). Findings conclude that the risk of financial distress, leverage, and free cash flow have a significant relationship with earnings management among Shariah-compliant
\end{abstract}

companies. This study provides evidence that further improvements on corporate governance are necessary to ensure that Shariah-compliant companies adhere with the Shariah requirement.

Keywords: Managerial Opportunism; Real Earnings Management; Shariah-compliant Companies; Free Cash Flow; Financial Distress

\section{Introduction}

The scrutiny toward the accounting and auditing professions is escalating. Recent appalling corporate scandals in Asia (see Appendix A), such as Satyam, Olympus Corp, Toshiba, Daewoo Shipbuilding \& Marine Engineering, and Transmile Berhad, have drawn considerable attention toward managerial opportunistic behaviors in practicing earnings management. Healy and Wahlen (1999) explained that "earnings management happens when managers alter financial reports with the intention to either mislead readers of those statements or to influence contractual outcomes 
that rely on the accounting numbers reported in the financial statements." Nevertheless, earnings management involves the selection of accounting procedures and estimates that conform to generally accepted accounting principles (GAAP). Management has flexibility in the choice of accounting policy, thereby enabling a flexible response to accommodate the changes in a firm's environment and unforeseen circumstances. Furthermore, management allows for opportunistic management behavior. Hence, Shariah-compliant companies are perceived to avoid earnings manipulation, any unethical transactions, and any matters that have adverse effects on the investment activities of a company (Abdul Rahman, Rahman and Courtney, 2010; Alam, Hassan, and Said, 2015).

The existing literature has identified several motivations for managers to engage in earnings management, such as compensation incentives, capital market pressure, financial risk, regulatory incentives, and political costs. Given that opportunistic behavior is prohibited in Islam, Muslims are anticipated to behave in accordance with the tenets of their religion, which should be reflected in management behavior and company actions (Ghani and Said, 2010). However, moral glitch could happen due to unforeseen circumstances and ethical issues. This study focuses on the aspect of financial risk in addressing opportunistic behavior and investigates the relationships of risk of financial distress (z-score), leverage, and free cash flows on earnings management in Shariah-compliant companies.

The findings of this study will be beneficial for the Shariah Advisory Council in formulating criteria and screening processes for Shariahapproval that cover activities or investments that adhere to Shariah, as well as include sources of financing, particularly the use of debt, and opportunistic behavior of earnings management in financial reporting. Improved guidelines and regulations would enhance the credibility of Islamic equity products and the security and confidence of Islamic investors.
The following sections discuss the literature review, methodology, analysis, and conclusion of this study.

\section{Literature review}

\section{Islamic Capital Market in Malaysia}

The Malaysian capital market is distinct from the other Asian capital markets. In the former, two types of market operate in parallel, namely, Islamic and conventional markets. The Islamic capital market (ICM) is globally renowned and is positioned as an additional option for financial products and services available in the international market. Meanwhile, in Malaysia, ICM is a vibrant component of the capital market by offering a wide range of Shariah-compliant equity products, debts securities, and managed funds. Apart from generating economic growth for Malaysia, ICM plays a complementary role to the Islamic banking system in broadening and deepening the Islamic financial markets in this country. As of 2013, approximately $88 \%$ of the companies listed on Bursa Malaysia are Shariah-compliant companies (Securities Commission, 2013). Thus, the contribution of these companies toward the Malaysian economy is significant and requires considerable attention to ensure that such contributions are sustainable.

ICM is developed by adopting specific screening processes that are based on various considerations. Screening criteria are explicitly employed to ensure that the business and investment activities of a Shariah-compliant company are consistent with Shariah law. Shariah law is apprehensive with the moral or ethical value of commercial transactions. From the Shariah-compliant investment point of view, the key element to equity funds is the screening criteria, which had been used to determine the status of companies in which an investment is to be made by the funds (Imtiaz Shah, 2008). To qualify as a Shariah-compliant company, a company has to prove that the primary business and investment activities that generate its income conform with the Shariah principles 
(Abdul Rahman, Al Smady, \& Kazemian, 2015).

Given the rigidity of Islamic principles, the development of ICM requires in-depth understanding of Shariah law, capital market operations, and contemporary analysis (Abdul Rahman, 2007). The Securities Commission, which is aided by the Shariah Advisory Council, is responsible for all related matters regarding ICM and acts as the general reference center for Islamic finance. The Securities Commission, together with other regulators, acts as the superior watchdog that oversees the Malaysian capital market. This commission also plays a vital role in formulating a facilitative regulatory framework to strengthen and sustain the position of Malaysia as an international hub for Islamic finance (Darus, Amran, Nejati, and Yusoff, 2014).

At present, several screening methods have been developed and approved by globally renowned Islamic scholars. The lack of a standardized screening process necessitates that fund managers select the screening process based on the corresponding Shariah council. In Malaysia, the Shariah Advisory Council (SAC) of the Securities Commission recently employed the Dow Jones-RHB Islamic Malaysia Index and FTSE Global Islamic Index Series as part of their screening process. Companies that comply with Shariah are classified as Shariah-compliant securities, whereas those that are non-compliant are classified as non-Shariah compliant. The aforesaid index uses market information, research, and advice from Shariah scholars to provide screen stocks for Shariah compliance and publishes information on which equities Muslims can trade in without breaching the requirement of Islamic principles (Ali, 2008). Given that Malaysia aims to be the Islamic financial hub across the region, the government exerted effort to harmonize and address Shariah compliance issues for promoting and attracting domestic and international investment participation (Kazemian, Abdul Rahman, and Ibrahim, 2014).
In Malaysia, Shariah-compliant stock means that the securities of a company listed on Bursa Malaysia have been awarded and classified as Shariah permissible for investment. To qualify for this classification, a company has to prove that the primary business and investment activities that generate its income conform with Shariah principles. The variety of Islamic equityrelated products includes Shariah-compliant stocks listed on the Main and ACE Market Bursa Malaysia, two Shariah indices, and equity derivatives (e.g., warrants, transferable subscription rights (TSRs) of approved securities, index, and composite future). The Islamic equity market is characterized by the absence of interest-based transactions, doubtful transactions, and unlawful stocks of companies that deal in non-Shariah compliance activities or items. Any activities in the market must be free of any form of unethical or immoral elements (Securities Commission Malaysia, 2013). Shariah principles fundamentally protect businesses and investors, consumers and producers, the community, and the country from the unfairness of any deceitful and treacherous business dealings.

The Islamic Shariah had already provided the proper and appropriate behavioral conduct code for Muslims; hence, the sense of responsibility and caution by management should be enhanced due to religiously enthused investments. Thus, a significant positive improvement is expected in business developments around the world because of the availability of Shariah-compliant securities. Such positivity could be explained by the argument that the basis for civilized behavior could result in changes in accountability and moral behavior (Scheling, 1968; Durant, 1950).

\section{Uniqueness of Shariah-compliant Companies}

Good corporate governance includes the values of accountability, transparency, responsibility, and integrity (Omar, 2005); these values are paramount as a way of life in Islam. Nonetheless, Islam significantly emphasizes the need for Muslims to be accountable to God and to 
their fellow men. Moreover, Islam does not compartmentalize its way of living and separates religious deeds from political, economic, and social affairs. Although Islam encourages entrepreneurship and involvement in business activities, Fiqh (Islamic law) prescribes the nature of allowable trade and services, which generally entails accountability, transparency, and integrity. Fiqh explicitly forbids business dealings that are ambiguous, unfair, unjust, and fraudulent. These particular traits of Islamic finance have generally influenced its global expansion with Muslims and non-Muslims as consumers.

Anuar, Sulaiman, and Nik Ahmad (2004) used a sample of Shariah-approved companies and analyzed the extent of the environmental reporting of Shariah-approved companies in Malaysia. They concluded that Shariahcompliant companies have a higher level of environmental disclosure compared with non-Shariah-compliant companies. These researchers assert further that the considerable extent of environmental disclosure may reflect an attempt to embody the Islamic principle of full disclosure and social accountability.

Mohd Dali, Mudasir, and Abdul Hamid (2008) employed a sample of Malaysian Shariah-approved companies in the plantation industry to fulfill the demand of investors for information with which to analyze company performance and accumulation of wealth in accordance with Shariah law. These researchers used multiple discriminant analysis (MDA) and multiple regressions to distinguish between performing and under-performing companies; they determined that most Shariah-compliant companies are good performers. AbdulRahman, Rahman, and Courtney (2010) conducted a study on religion, ethical values, and earnings management and determined that the implementation of religious ethics in company policy influences the tendency to manage earnings.

\section{Managerial Opportunism and Earnings Management}

Agency theory indicates that the separation of ownership and control and the different levels of risk preferences lead to a divergence of interests between managers and shareholders (Jensen and Meckling, 1976). Consequently, managers tend toward fulfilling their personal interests, which is considered an opportunistic behavior, through earnings management. Earnings management practices include income smoothing, systematic allocations, discretionary provisions, and creative accounting. These techniques, although misleading, still conform with GAAP. The current study established the link between real earnings management and the risk of financial distress, leverage, and free cash flow based on two competing views, namely, moral obligation and opportunistic behavior.

Schipper (1989) defined earnings management as a snaking method in preparing financial statements to acquire personal benefits. Correspondingly, Healy and Wahlen (1999) defined earnings management as an opportunistic behavior, in which managers willingly opt for preferred reporting methods and estimations that did not accurately reflect the underlying economic performance of a firm. A diverse definition by Giroux (2004) indicated that earnings management comprises an entire range of accounting decisions (from conservative to fraud) and asserts that the wide range of accounting judgments provide incentives to management. He considered earnings management as a dynamic process that may change from one quarter to another, and meeting the expectations of financial analysts is important. Within this approach, Giroux (2004) further defined earnings management as a practice in financial reporting toward objectives and plan. Meanwhile, Ronen and Yaari (2008) offered an alternative view of earnings management and summarize different definitions of earnings management by classifying them as white, black, and gray. 
Earnings management is considered beneficial (white) if it enhances the transparency of reports, pernicious (black) if it involves outright misrepresentation and fraud, and gray if the manipulation of reports is within the boundaries of compliance with bright-line standards, which could be either opportunistic of efficiency enhancing (Ronen and Yaari, 2008).

The definitions of earnings management may differ depending on the instruments of manipulation, purpose of the earnings management behavior, and its timing (Kazemian and Mohd-Sanusi, 2015). Although defined in a variety of ways, the previous literature on the definition of earnings management generally agrees that the practice comprises elements of an action purposely undertaken to alter the information in financial statements to mislead their user. The motives behind earnings management can be explicitly observed in an improved compensation package, career advancement, and job security, thereby preventing violations of loan contract, reducing regulatory costs, and enhancing any foreseeable benefits in relation to the business and the management. If such indiscretion is normally performed by managers to acquire personal benefits, then such manager exhibits opportunistic behavior, which is prohibited in Islam (Al-Kashif, 2009; Mohd-Sanusi, Ismail, Hudayati, and Harjito, 2015).

The two categories of earnings management are accruals earnings management (AEM) and real earnings management (REM). Dechow and Skinner (2000) explained that AEM occurs when managers attempt to hide true economic performance by manipulating reported earnings through exploiting accounting discretion that GAAP allows. AEM typically involves manipulation of earnings that include accounting estimates and accounting choices with no direct effects toward cash flow. Meanwhile, REM happens when managers attempt to influence the output of financial reporting by adjusting the timing and scale of underlying business activities (e.g., financing, investment, or operating activity) on the reported earnings.

Cohen and Zarowin (2010) explained that managers are shifting away from practicing AEM to REM in the period following the Sarbanes Oxley Act 2002 because it is considerably unlikely to be detected and scrutinized by external auditors and regulatory bodies. Abdul Rahman, Sulaiman, Fadel, and Kazemian, 2016; Roychowdhury (2006); Baderstscher, Phillips, Pincus, and Rego (2009); and Cohen and Zarowin (2010) argued that REM is substantially hazardous and costly as it involves cash flow consequences. Furthermore, Gunny (2010) asserted that REM is highly likely to result in negative impact on future performance. As such, the current study underscores the association between REM as a proxy for EM and firm value.

The harmonization of Shariah principles and current business affairs has become a norm in business transactions, as well as provides an overview and appreciation of full compliance with Islamic law (Falaika, 2002). Thus, a thorough compliance by Shariahcompliant companies toward the Shariah law is imperative because Muslim investors would only show interest to invest when such compliance is warranted. Faishal, Eng, and Ali (2009) conducted a study on Shariah property investment in Asia and determined that over $95 \%$ of the respondents favor Shariah-compliant companies that completely comply with "halal" type of business structure.

Farooq and Abdel Bari (2015) determined that Shariah-compliant companies engage in lower earnings management than non-Shariahcompliant firms do. Alsaadi, Ebrahim, and Jaafar (2017) determined that in non-Shariahcompliant European firms, proponents of corporate social responsibility are less likely to manipulate their earnings compared with their counterpart. These researchers suggested that the current Shariah screening process should be improved to reflect and fully conform to underlying Islamic principles. Previous studies indicate that Southeast Asia had the highest 
potential in attracting Shariah-compliant real estate investment. As such, ICM seems to be a significant opportunity for Malaysian economy to prosper. However, extensive measures are necessary to ensure that Shariah laws are implemented.

\section{Hypothesis Development}

Dichev, Graham, Harvey, and Rajgopal (2013) explained that the three most common indicators that a company is managing earnings are persistent deviations between earnings and underlying cash flows, deviations from what other companies in the same sector are reporting, and large unexplained accruals or changes in accruals. Their findings corroborate the earlier literature on earnings management, such as Roychowdhury (2006), Matsumoto (2002), Kazemian, et al., (2017), and Ujah and Brusa (2011). However, the degree and extent of earnings management varies and often depends on the type of economic group or industry (Ujah and Brusa, 2011). Beneish (2001) determined that certain sectors have more incentives to manage earnings than others have.

The risk of financial distress could be another reason why earnings management prospers. If a firm is in financial distress, then company managers can expect to have their bonuses cut, be replaced, and suffer loss of reputation (Liberty and Zimmerman, 1986; Gilson, 1989). Therefore, conventional wisdom suggests that managers have incentives to conceal such a deteriorating performance by resorting to accounting choices that increase income. However, empirical evidence is inconclusive. Rosner (2003) documented that firms that become bankrupt ex post but do not appear distressed ex ante engage in income-increasing earnings manipulation practices. DeAngelo et al. (1994) determined that managers reduce income via negative abnormal accruals and discretionary write-offs instead of inflating income. Chen et al. (2010) determined that distressed firms in China employ incomeincreasing earnings management techniques to avoid a delisting threat and special monitoring treatment from the government. The following hypothesis is anticipated given the inconclusive evidence on the association between financial distress and earnings management:

\section{H1: A significant relationship exists between financial distress and earnings management in Shariah-compliant Malaysian companies.}

High leverages are often viewed as a bad investment choice and are often associated with substantial risk. Ahorany et al. (1993) and Defond and Jimbalvo (1994) explained that heavily leveraged firms are considerably prone to manipulate earnings because managers tend to manage earnings upwards to avoid technical default, or downwards to facilitate renegotiation of debt contracts. Similarly, Sweeney (1994) reported that managers use discretionary accruals to satisfy debt covenant requirements. Inversely, Park and Shin (2004) claimed that highly indebted firms may be unable to practice earnings management because they are under close scrutiny by the stakeholders. Nevertheless, Sun and Rath (2009); Abdul Rahman and Mohamed Ali (2008); Abdul Rahman, Dowds, and Cahan (2005); Bedard et al. (2004); and Jones and Sharma (2001) determined no significant relationship between earnings management and leverage. The inconsistency in previous studies leads to the following hypothesis:

\section{H2: A significant relationship exists between leverage and earnings management in Shariah-compliant Malaysian companies.}

Free cash flow is another attribute that has been identified to affect the level of earnings management. Jensen (1986) explained that conflicts of interest would emerge between shareholders and managers over payout policies, and are particularly significant when companies have substantial free cash flow. Jensen and Meckling (1976) alleged that managers are prone to use free cash flow to finance projects with negative net present values with the intention of fulfilling their personal interest. Chung et al. 
(2005) investigated the relationship between earnings management and free cash flows in firms with low growth from 1984 to1996. Their research sample consists of 22576 American firms. Their empirical study determined that companies with low growth and high free cash flow would use income-increasing discretionary accruals to offset low earnings or negative earnings caused by investments with negative present values. An independent audit committee assists companies with high surplus free cash flow to reduce income-increasing earnings management practices (Bukit and Iskandar, 2009). Therefore, the third hypothesis is as follows:

\section{H3: A significant relationship exists between free cash flow and earnings management in Shariah-compliant Malaysian companies.}

\section{Methodology}

\section{Sample selection}

The population of interest in this study covers Shariah-compliant companies listed in the Securities Commission in 2009 and continuously listed until 2013. Data on Shariah status companies listed in Bursa Malaysia were gathered from the latest listing of the Securities Commissions of Shariah-compliant companies. A total of 694 of Shariah-compliant companies were identified for the analysis, making up for the secondary data consisting of financial statements component.

\section{Measurement of the Dependent Variables}

Prior research mainly employs accrual-based measures as a proxy of earnings management. However, managers can use real activities, apart from the accrual process, to manage earnings. REM refers to real actions that affect earnings to achieve a specific reported earnings objective (Scott, 2011). REM negatively affects future firm performance because a manager is willing to sacrifice future cash flows for current period income (Cohen and Zarowin,
2010). Roychowdhury (2006) explained that the manipulation of real activities includes actual activities, such as price discounts and reduction of discretionary expenditures that are done extensively in a normal economic condition.

Bruns and Merchant (1990) and Graham et al. (2005) explained that financial executives indicate considerable willingness to manipulate earnings through real activities rather than accruals. Thus, REM may be the appropriate measure of earnings management for the current study. Following Roychowdhury (2006), the current study focuses on the abnormal level of the cost of goods sold and abnormal level of discretionary expenses as the proxies for earnings management. This study uses equations $\mathrm{A}$ and $\mathrm{B}$ as follows:

\section{(A) Normal Level of Cost of Goods Sold (COGS)}

COGSt $/$ At $-1=\alpha 0+\alpha 1(1 / A t-1)$

$+\beta 1(S t / A t-1)+\varepsilon \mathrm{t}$

Where: $\mathrm{COGS}_{\mathrm{t}}=$ Cost of goods sold (current year)

At $-1=$ Total assets (previous year)

St $\quad=$ Sales (current year)

Equation 1 is based on Roychowdhury (2006). The residual value will include the suspected firms engaged in abnormal COGS, as well as their residual value if the normal intensity of COGS varies with the actual amount of COGS.

\section{(B) Normal Level of Discretionary Expenses (DISEXP) \\ $\operatorname{DISEXP}_{\mathrm{t}} / \mathrm{At}_{\mathrm{t}-1}=\boldsymbol{\alpha}_{0}+\boldsymbol{\alpha}_{1}\left(1 / A_{t-1}\right)$ \\ $+\beta_{1}\left(S_{t-1} / A_{t-1}\right)+\varepsilon_{\mathrm{t}}$}

Where: DISEXPt $=$ Discretionary expenses (current year)

At $-1=$ Total assets (previous year)

St $-1=$ Sales (previous year) 
Equation 2 is based on Roychowdhury (2006) as well. A residual value exists if the normal intensity of DISEXP varies with the actual amount of DISEXP. Suspected firms are firms with residual values based on linear regression.

\section{Measurement of Independent Variables}

The Z-score model was developed by Altman (1968) and selected as the proxy of the risk of financial distress. Oluwo (2007) explained that this model can be used as a tool to learn and predict the financial health of a company. The Z-score model includes working capital over total assets, retained earnings over total assets, earnings before interest and taxes over total assets, market value of equity over book value of total debt, and sales over total assets. The formula for the Z-score is as follows:

$Z=1.2 x(1)+1.4 x(2)+3.3 \times(3)+0.6 x(4)+$ $1.0 x(5)$

Where:

$\mathrm{Z}=$ overall classification index

$\mathrm{x}(1)=$ working capital over total assets

$\mathrm{x}(2)=$ retained earnings over total assets

$\mathrm{x}(3)=$ earnings before interest and taxes over total assets

$\mathrm{x}(4)=$ market value of equity over book value of total debt

$\mathrm{x}(5)=$ sales over total assets

To determine the financial health of a company, Altman's model was divided into three zones as a result of discrimination. The three zones are below 1.81 (distress zone), between 1.81 and 2.99 (grey zone), and above 2.99 (safe zone). Any point above 2.88 indicates that a company's financial health is sturdy. If any company was in the zone of discrimination of 1.81 and below, then such company is considered having financial problems and facing the risk of bankruptcy. Discrimination zones between 1.81 and 2.99 were considered zones of ignorance, in which companies have the possibility to misclassify their financial information. Thus, the cut-off of account point of 2.675 would decide whether a company had financial problems, and anything below that point would be considered a business failure (Oluwo, 2007).

Leverage ratios would indicate the level of long-term debt with long-term measures in the company balance sheet. The following equation was used to measure debt to equity ratio (DTE): DTE $=$ Debt/Total Equity and Debt to Assets ratio $(\mathrm{DTA})=$ Total Debt/Total Assets. If the existing leverage was high, then the probability of a company management violating a loan agreement is likely high. Moreover, a significant leverage would prevent a company from obtaining additional capital through loans.

The suggestion is that relative cash flow has a negative relationship with discretionary accounting accruals (Becker, DeFond, Jiambalvo and Subramanyam, 1998). Excessive cash flow indicates that profits are high, thereby encouraging companies to accept low income discretionary accounting accruals to income smoothing. To control the potential impact on cash flow, the current study included indicator changes as relative cash flow. Following Chung et al. (205), free cash flow was measured by the cash flow for the year divided by the total assets lagged (year $\mathrm{t}-1$ ). Therefore, a negative sign was expected, thereby signifying a tendency flow with relatively high cash to practice dressing windows on account of a particular income.

\section{Measurement of Control Variables}

This study uses two control variables, namely, firm size and type of auditor. The size of the client log of total assets is measured due to the significant relationship between firm size and discretionary accruals. Dechow and Dichev (2004) and Choi et al. (2010) advocated this method to control the influence of the size of the client in the quality of accruals (earnings management). Similarly, Srinidhi and Gul (2007) included the size of their customer as control variables to measure the log of the total assets. Rationally, the public would scrutinize a large 
firm; however, the density and complexity of such a large firm provide additional opportunities for earnings management (Siregar and Utama, 2008).

Becker et al. (1998) and Francis et al. (1999) explained that engaging with a large audit firm would deter earnings manipulation because such firm is expected to provide high-quality audit services. However, Libby and Kinney (2000) presented an opposite opinion by suggesting that the big five auditors may allow their clients to engage in income-increasing accounting misstatements. The conflicting results of previous studies have resulted in the inclusion of the dummy variable for audit types in the current study to analyze whether this variable would have an effect on a firm's value.

Thus, the estimation model is as follows:

REM $=$ Altman Z-score + Free Cash Flow + Leverage + Firm Size + Type of Auditor

The following are the estimation models for each REM activities:

(a). COGS $=$ Zscore + FCF + LEV + LOGTA + TA

(b). DISEXP $=$ Zscore + FCF + LEV + LOGTA + TA

\section{Results and Discussion}

\section{Descriptive Analysis}

Tables 1 and 2 present the minimum, maximum, mean, standard deviation, skewness, and kurtosis for the variables used in this study. The first rows in Tables 1 and 2 show the earnings management (EM) with abnormal COGS and abnormal DISEXP, respectively, as used by Roychowdhury (2006). Overall, most of the variables had positive skewness and kurtosis, thereby indicating that most of the data were distributed at positive values and clustered in the center. This information and the shape of distribution on the histogram indicate that data were near the normal distribution and suggest no violation of the assumption of normality.

\section{Pearson's Correlation Product Moment}

Tables 3 and 4 illustrate the relationship between the dependent and independent variables. Abnormal DISEXP has a positive correlation with the risk of financial distress of a firm ( $\mathrm{r}$ $=0.064, p<0.01)$. The findings imply that companies with a high risk of financial distress would face considerably high probability of bankruptcy and are likely to manage earnings. The Abnormal COGS and Abnormal DISEXP show significant correlation with free cash flow (Abnormal COGS with $r=0.272$ and Abnormal DISEXP with $r=0.247, p<0.01$ ). The result shows that the probability of managers engaging in earnings management is high if a company retains excessive cash flow (free cash flow). In this situation, a manager would be typically inclined to invest in a non-value investment and misuse the fund for personal gain. The findings for both models indicate that the higher the leverage of a firm, the higher the probability of earnings management being practiced. That is, the manager in a firm with high leverage would have considerably high intention to engage in earnings management to avoid debt covenant violations.

The size of a firm shows significant correlation with earnings management. However, only the Abnormal COGS were significant $(\mathrm{r}=$ $0.042, \mathrm{p}<0.05)$. Although both models show positive relationship with the type of auditor, the results are not significant. However, the risk of financial distress has negative correlation with leverage (Abnormal COGS with $\mathrm{r}=-0.023$ and Abnormal DISEXP with $r=-0.017$ ). This result verifies the assumption that low level of leverage does not lead a company to financial distress. Moreover, the risk of financial distress has negative correlation with free cash flow (Abnormal COGS with $r=-0.021$ and Abnormal DISEXP with $r=-0.007)$. This finding confirms the notion that firms with a high level of leverage are not healthy financially and have limited free cash flow. 
GJAT | JANUARY 2018 | SPECIAL ISSUE| 108

ISSN : 2232-0474 | E-ISSN : 2232-0482

www.gjat.my

Table 1: Descriptive Statistics for the Abnormal COGS

\begin{tabular}{|c|c|c|c|c|c|c|}
\hline & Mean & Minimum & Maximum & $\begin{array}{l}\text { Standard } \\
\text { Deviation }\end{array}$ & Skewness & Kurtosis \\
\hline Residual & 0.3084 & 0.00 & 61.13 & 1.6669 & 26.91 & 8.1899 \\
\hline FCF & 1.1042 & -9.8118 & 8.6447 & 6.0480 & 4.352 & 1.0059 \\
\hline LEV & 0.2628 & 0.00 & 16.71 & 0.75717 & 14.507 & 2.6676 \\
\hline AUD & 0.5062 & 0.00 & 1.00 & 0.50005 & -0.025 & -2.001 \\
\hline
\end{tabular}

The abbreviations of Residual represents abnormal COGS, ZSCORE represents risk of financial distress, FCF represents free cash flow, LEV represents leverage, LogAsset represents firm size, and AUD represents type of auditor.

Table 2: Descriptive Statistics for the Abnormal DISEXP

\begin{tabular}{|c|c|c|c|c|c|c|}
\hline & Mean & Minimum & Maximum & $\begin{array}{l}\text { Standard } \\
\text { Deviation }\end{array}$ & Skewness & Kurtosis \\
\hline Residual & 0.8144 & 0.00 & 97.18 & 3.18577 & 18.650 & 4.5265 \\
\hline $\mathrm{FCF}$ & 1.0031 & -9.8118 & 7.1170 & 5.36814 & 3.835 & 1.0961 \\
\hline LEV & 0.2579 & 0.00 & 16.71 & 0.69868 & 14.765 & 2.8832 \\
\hline AUD & 0.5024 & 0.00 & 1.00 & 0.50010 & -0.010 & -2.002 \\
\hline
\end{tabular}

The abbreviations of Residual represents abnormal DISEXP, ZSCORE represents risk of financial distress, FCF represents free cash flow, LEV represents leverage, LogAsset represents firm size, and AUD represents type of auditor.

Table 3: Pearson's Correlation for Abnormal COGS

\begin{tabular}{|c|c|c|c|c|c|c|}
\hline Variables & Residual & Zscore & FCF & LEV & LOGTA & AUD \\
\hline Zscore & & 1 & -0.021 & -0.023 & $-0.031 *$ & $0.50 * *$ \\
\hline $\mathrm{FCF}$ & & & 1 & $0.164 * *$ & $0.713 * *$ & $0.141^{* *}$ \\
\hline LEV & & & & 1 & 0.043 & -0.018 \\
\hline
\end{tabular}

*Correlation is significant at the 0.05 levels (2- tailed) $\quad * *$ Correlation is significant at the 0.01 levels $(2-$ tailed)

Table 4: Pearson's Correlation for Abnormal DISEXP

\begin{tabular}{|c|c|c|c|c|c|c|}
\hline Variables & Residual & Zscore & FCF & LEV & LOGTA & AUD \\
\hline Zscore & & 1 & -0.007 & -0.017 & -0.024 & $0.70 * *$ \\
\hline FCF & & & 1 & $0.211 * *$ & $0.718 * *$ & $0.149 * *$ \\
\hline LEV & & & & 1 & $0.035^{*}$ & -0.011 \\
\hline
\end{tabular}

*Correlation is significant at the 0.05 levels (2- tailed) $\quad * *$ Correlation is significant at the 0.01 levels $(2-$ tailed) 
For the Abnormal DISEXP, a significant relationship exists between firm size and leverage $(\mathrm{r}=0.035, \mathrm{p}<0.05)$. A larger firm would normally indulge with the possibility of obtaining more loans compared with smaller firms. Firm size and free cash flow are significant (Abnormal COGS with $r=0.713$ and Abnormal DISEXP with $r=0.718, p<0.01$ ). This finding shows that a large firm has substantial free cash flow. The aforementioned findings indicate that a large firm is likely to take up additional loans, of which high leverage could increase the probability of being in financial distress and have substantial free cash flow. Thus, managers are likely to manage earnings.

\section{Regression Analysis}

\section{Regression Analysis of the Pooled Data}

Tables 5(a) and (b) present the regression results for the pooled data to test the first, second, and third hypotheses.

All accounted variables would influence earnings management practices (see Tables 5(a) and (b)). Table 5(b) shows a significant relationship between the risk of financial distress and earnings management. The findings support the previous studies of Spathis (2002) and Barsky et al. (2003). The high risk of financial distress would result in companies becoming considerably prone to engage in earnings manipulation because managers would want to reduce the risk of bankruptcy by showing favorable earnings in the financial report. Hence, hypothesis 1 is accepted.

The relationship between free cash flow and earnings management is significant (see both tables). The result suggests that high level of free cash flow would increase the risk of earnings manipulation; this result is consistent with the findings of Gul (2001), Chung et al. (2005), and Bukit and Iskandar (2009). For example, managers could handle earnings such that free cash flow balances with the total assets. Thus, hypothesis 2 is accepted.

An analysis of the relationship between leverage and earnings management indicates that the third hypothesis is accepted. The relationship between leverage and REM activities are generally expected to be positively associated. To ensure that debt covenants are not violated, managers would be motivated to understate liabilities or overstate assets if a company lacks the ability to obtain additional capital through borrowing. Seemingly, being in a state of indebtedness imposes considerably high probability for a company to manage earnings.

The log total asset (proxy for firm size) shows significant result toward earnings management.

Table 5(a): Regression Results for the Abnormal COGS

\begin{tabular}{|c|c|c|c|c|c|}
\hline & \multicolumn{2}{|c|}{ Unstandardized Coefficients } & \multirow{2}{*}{$\begin{array}{c}\begin{array}{c}\text { Standardized } \\
\text { Coefficients }\end{array} \\
\text { Beta }\end{array}$} & \multirow[t]{2}{*}{$\mathrm{t}$} & \multirow[t]{2}{*}{ Significant } \\
\hline & Beta & Std. Error & & & \\
\hline (Constant) & -0.055 & 0.040 & & -21.355 & 0.175 \\
\hline Zscore & 0.033 & 0.017 & 0.029 & 1.949 & 0.051 \\
\hline FCF & 9.694 & 0.000 & 0.352 & $16.407 * * *$ & 0.000 \\
\hline LEV & 1.134 & 0.033 & 0.515 & $34.287 * * *$ & 0.000 \\
\hline AUD & 0.042 & 0.050 & 0.013 & 0.846 & 0.398 \\
\hline LOGTA & -6.924 & 0.000 & -0.232 & $-10.955 * * *$ & 0.000 \\
\hline $\mathrm{R}^{2}$ & 0.376 & & & & \\
\hline Adjusted $\mathrm{R}^{2}$ & 0.375 & & & & \\
\hline F-Statistic & $347.129 * * *$ & & & & \\
\hline
\end{tabular}

***Significant at the 0.001 level (Sig 2 - tailed) $\quad * *$ Significant at the 0.01 (Sig 2 -tailed) * Significant at 0.05 level (Sig 2 - tailed) 
GJAT | JANUARY 2018 | SPECIAL ISSUE| 110

ISSN : 2232-0474 | E-ISSN : 2232-0482

www.gjat.my

Table 5(b): Regression Results for the Abnormal DISEXP

\begin{tabular}{|c|c|c|c|c|c|}
\hline & \multicolumn{2}{|c|}{ Unstandardized Coefficients } & \multirow{2}{*}{$\begin{array}{c}\begin{array}{c}\text { Standardized } \\
\text { Coefficients }\end{array} \\
\text { Beta }\end{array}$} & \multirow[t]{2}{*}{$\mathrm{t}$} & \multirow[t]{2}{*}{ Significant } \\
\hline & Beta & Std. Error & & & \\
\hline (Constant) & -0.032 & 0.082 & & -0.395 & 0.693 \\
\hline Zscore & 0.168 & 0.038 & 0.069 & $4.466 * * *$ & 0.000 \\
\hline FCF & 1.964 & 0.000 & 0.331 & $14.454 * * *$ & 0.000 \\
\hline LEV & 2.623 & 0.073 & 0.575 & $36.146^{* * *}$ & 0.000 \\
\hline AUD & 0.44 & 0.099 & 0.007 & 0.439 & 0.661 \\
\hline LOGTA & -1.713 & 0.000 & -0.287 & $-12.811 * * *$ & 0.000 \\
\hline $\mathrm{R}^{2}$ & 0.459 & & & & \\
\hline Adjusted $\mathrm{R}^{2}$ & 0.458 & & & & \\
\hline F-Statistic & $391.413 * * *$ & & & & \\
\hline
\end{tabular}

***Significant at the 0.001 level (Sig 2 - tailed) $\quad * *$ Significant at the 0.01 (Sig 2 -tailed) * Significant at 0.05 level (Sig $2-$ tailed)

However, firm size in this study is negatively associated with earnings management. This finding is inconsistent with that of Short and Keasey (1999) because the latter shows that firm size has a positive significant effect on firm performance. The result of the current study provides different signals because the common assumption is that a large firm provides managers with extensive opportunities to manage earnings. For the type of auditor, both results are not significant.

\section{Conclusions}

The main purpose of this study is to analyze whether earnings management occurs in Shariah-compliant Malaysian companies. An empirical investigation was conducted using a sample of Shariah-compliant companies from all industries, and were listed on Bursa Malaysia from 2009 to 2013. Regression analysis was used to test all the hypotheses on the final sample of 694 Shariah-compliant companies. Following Roychowdhury (2006), the current study uses the abnormal cost of goods sold and abnormal discretionary expenses as proxies for earnings management. Three hypotheses on financial distress, leverage, and free cash flow were tested; all hypotheses were verified and accepted. Accordingly, managers of firms with financial distress, with substantial leverage, and overflowing free cash flow could manage company earnings.
The result obtained for the main objective of this study reveals that earnings management occurs in Shariah-approved Malaysian companies. Earnings management reflects the opportunistic behavior of management, which Islam prohibits; however, this situation still occurs. In line with the Malaysian government objective of becoming a global hub for the Islamic finance industry, regulatory bodies, particularly the Shariah Advisory Council, should consider revising the criteria and screening process for Shariah-approved status of listed companies on Bursa Malaysia. Moreover, considering the characteristics and current trends of earnings management practice, the findings of this study would create awareness, provide guidance to boards, and simultaneously enhance public confidence in the Islamic capital market.

However, limitations that could influence the underlying factors could yield insignificant results. Although a sample of five-year period was used, this study is considered moderate compared with previous studies. Future research may consider a considerably long time frame with the resulting impact of other regulations related to Shariah-approved companies, earnings management, and corporate governance released by regulatory authorities. A comparative research could be conducted to analyze pre- and post-regulation periods related to corporate governance and earnings management. Moreover, future research could be extended to all companies in general, thereby 
providing a comparison with Shariah-approved companies. In addition, future research in the area of Shariah-approved stock markets may be conducted in other countries with Islamic financial markets.

\section{Acknowledgements}

The authors would like to express their gratitude to the Accounting Research Institute (ARI), Ministry of Education, Malaysia and Universiti Teknologi MARA for funding and facilitating this research project.

\section{References}

Abdul Rahman, R., Al Smady, A., \& Kazemian, S. (2015). Sustainability of Islamic Microfinance Institutions through Community Development. International Business Research, 8(6), 196-207.

Abdul Rahman, R., \& Mohamed Ali, F. H. (2008). Board, audit committee, culture and earnings management: Malaysian evidence. Managerial Auditing Journal, 21(7), 783- 804.

Abdul Rahman, S. G. (2007). Foreword. In Resolutions of the Securities Commission of Shariah Advisory Council. Kuala Lumpur: Perpustakaan Negara Malaysia.

Abdul Rahman, R., Sulaiman, S., Fadel, E. S., \& Kazemian, S. (2016). Earnings Management and Fraudulent Financial Reporting: The Malaysian Story. Journal of Modern Accounting and Auditing, 12(2), 91-101.

Abdul Rahman, U. M., Dowds, J., \& Cahan, S. F. (2005). Earnings Management Practices Among Muslim and Non-Muslim Managers in Malaysia. IIUM Journal of Economics and Management, 13(2), 189-208.

Abdul-Rahman, R., Rahman, A., \& Courtenay S. (2010). Religion and earnings management - Some evidence from Malaysia. American Accounting Association Conference, New York, 1-5 August.
Alam, M. M., Hassan, S., \& Said, J. (2015). Performance of Islamic microcredit in perspective of Maqasid Al-Shariah: A case study on Amanah Ikhtiar Malaysia. Humanomics, 31(4), 374-384.

Ahorany, J., Lin, C.-J., \& Loeb, M. (1993). Initial public offerings, accounting choices, and earnings management. Contemporary Accounting Research, 10, 61-81.

Al-Kashif, A. E.-R. M. (2009). Shari'ah's normative framework as to financial crime and abuse. Journal of Financial Crime, 16(1), 86-96.

Ali, R. (2008). Islamic Finance: A Practical Guide. Globe Business Publishing, London.

Altman, E. I. (1968). Financial ratios, discriminant analysis and the prediction of corporate bankruptcy. The Journal of Finance, 23(4), 589-609.

Alsaadi, A., Ebrahim, M.S. \& Jaafar, A. J. (2017). Corporate Social Responsibility, Shariah Compliance, and Earnings Quality. Journal of Financial Services Research, 51(2), 169-194

Anuar, H. A., Sulaiman, M., \& Nik Ahmad, N. N. (2004). Environmental reporting of Shariah approved companies in Malaysia. International Islamic University Malaysia Accounting Conference II 19-20 February 2004 (pp. 1-17). Kuala Lumpur: International Islamic University Malaysia.

Badertscher, B., Phillips, J., Pincus, M., \& Rego, S. O. (2009). Evidence on motivations for downwards earnings management. Retrieved from http://ssrn.com/abstract $=921422$

Barsky, N. P., Catanach, A. H. \& RhoadesCatanach, S. C. (2003). Analytical tools for detecting financial reporting fraud. Commercial Lending Review, 18(5), 31-36. 
Becker, C. L., M. L. DeFond, J. Jiambalvo, \& Subramanyam, K. R. (1998). The effect of audit quality on earnings management. Contemporary Accounting Research, 15(Spring), 1-24.

Bedard, J., Chtourou, S. M., \& Courteau, L. (2004). The effect of audit committee expertise, independence, and activity on aggressive earnings management. Auditing, 23(2), 13-35.

Beneish, M. (2001). Earnings management: a perspective. Managerial Finance, 27, 3-17.

Benkel, M., Mather, P., \& Ramsay, A. (2006). The association between corporate governance and earnings management: The role of independent directors. Corporate Ownership and Control, 3(4), 65-75.

Bruns, W., \& Merchant, K. (1990). The dangerous morality of managing earnings. Management Accounting, 72, 22-25.

Bukit, R. B., \& Mohd Iskandar, T. (2009). Surplus free cash flow, earnings management and audit committee. International Journal of Economics and Management, 3(3), 204-223.

Chen, X., Cheng, Q., \& Wang, X. (2010). Does increased board independence reduce earnings management? Evidence from recent regulatory reforms. Working Paper, University of Wisconsin-Madison, Chinese University of Hong Kong.

Choi, J. H., Kim, J. B., \& Lee, J. J. (2010). Value relevance of discretionary accruals in the Asian financial crisis of 1997-1998. Journal of Accounting and Public Policy, forthcoming, 30(2), 166-187.

Chung, R., Firth, M., \& Kim, J.-B. (2005). Earnings management, surplus free cash flow, and external monitoring. Journal of Business Research, 58, 766-776.

Cohen, D. A., \& Zarowin, P. (2010). Accrualbased and real earnings management activities around seasoned equity offerings. Journal of Accounting and Economics. 50, 2-19.

Cohen, D. A., \& Zarowin, P. (2008). Accrualbased and real earnings management activities around Seasoned Equity Offerings. Retrieved 20/12/2012, from http://ssrn.com/ abstract=1081939 or http://dx.doi.org/10.2139/ ssrn.1081939.

Darus, F., Amran, A., Nejati, M., \& Yusoff, H. (2014). Corporate social responsibility towards the community: evidence from Islamic financial institutions in Malaysia. International Journal of Green Economics, 8(3-4), 273-287.

DeAngelo, H., DeAngelo, L., \& Skinner, D. J. (1994). Accounting choice in troubled companies. Journal of Accounting and Economics, 17, 113-143.

Dechow, P., \& Dichev, I. (2004). The Quality of Accruals and Earnings: The Role of Accrual Estimation Errors. The Accounting Review, 58, 766-776.

Dechow, P. M., \& Skinner, D. J. (2000). Earnings management: Reconciling the views of accounting academics, practitioners, and regulators. Accounting Horizons, 14(2), 235250.

DeFond, M. L., \& Jiambalvo, J. (1994). Debt covenant violation and manipulation of accruals. Journal of Accounting and Economics, 17(12), 145-176.

Dichev, I. D., Graham, J. R., Harvey, C. R., \& Rajgopal, S. (2013). Earnings quality: Evidence from the field. Journal of Accounting and Economics, 56, 1-33.

Durant, W. (1950). The Story of Civilization Part IV. The Age of Faith. New York: Simon and Schuster 
Falaika (2002). Islamic investment criteria. Retrieved June 1, 2009, from www.failaka. com/Failaka\%20Research.html.

Faishal M., I., Eng, O. S., \& Ali, P. (2009). Shariah Property Investment in Asia. Journal of Real Estate Literature, 17 (2), 233-248.

Farooq O., \& AbdelBari A. (2015). Earnings management behaviour of Shariah-compliant firms and non-Shariah-compliant firms: Evidence from the MENA region. Journal of Islamic Accounting and Business Research, 6(2), 173-188.

Francis, J. R., E. L. Maydew, \& Sparks, H. C. (1999). The Role of Big 6 Auditors in the Credible Reporting of Accruals. Auditing, 18(2), 17-34.

Gilson, S. (1989). Financial distress and management turnover. Journal of Financial Economics, 25, 241-262.

Giroux, G. (2004). Detecting earnings management. Hoboken: John Wiley and Sons.

Ghani, E., \& Said, J. (2010). Digital Reporting Practices Among Malaysian Local Authorities. Electronic Journal of e-Government, 8(1).

Graham, J. R., Harvey C. R., Rajgopal, S. (2005). The economic implications of corporate financial reporting. Journal of Accounting and Economics, 40, 3-73.

Gu, Z., Lee, C.W. J., \& Rosett, J. G. (2005). What determines the variability of accounting accruals? Review of Quantitative Finance and Accounting, 24, 313-334.

Gul, F. A. (2001). Free Cash Flow, Debt Monitoring and Managers' LIFO/FIFO Policy Choice. Journal of Corporate Finance, 13, 475492

Gunny, K. A. (2010). The relation between earnings management using real activities manipulation and future performance: Evidence from meeting earnings benchmarcks. Contemporary Accounting Research 27(3), 855888

Healy, P. M., \& Wahlen, J. M. (1999). A review on the earnings management literature and its implication for standard setting. Accounting Horizons, 13(4), 365-383.

Imtiaz Shah, (2008). Overview of Islamic asset management," in Islamic Finance: A Practical Guide. Globe Business Publishing Ltd.

Jamaluddin, S. (2003). Understanding The framework of business in Islam in an era of globalization: a review. Business Ethics: European Review, 12(1), 23-32.

Jensen, M. C. (1986), Agency costs of free cash flow, corporate finance, and takeovers, American Economic Review, 76, 323-329.

Jensen, M. C., \& Meckling, W. H. (1976). Theory of the firm: Managerial behavior, agency costs and ownership structure. Journal of Financial Economics, 3(4), 305-360.

Jones, S., \& Sharma, R. (2001). The impact of free cash flow, financial leverage and accounting regulation on earnings management in Australia's 'old' and 'new' economies. Managerial Finance, 27(12), 18-39.

Jordon, C. E., Clark, S. J., \& Pate, G. R. (2008). Earnings manipulation to achieve cognitive reference points in income. Academy of Accounting and Financial Studies Journal, 12(3), 97-112.

Kazemian, S., Abdul Rahman, R., \& Ibrahim, Z. (2014). Measuring level of market orientation for an Islamic microfinance institution case study of Amanah Ikhtiar Malaysia (AIM). Qualitative Research in Financial Markets, 6(3), 258-277. 
Kazemian, S., Ahmad Shauri, N. A., Mohd Sanusi, Z., Kamaluddin, A., \& Mohamed Shuhidan, S. (2017). Monitoring mechanisms and financial distress of public listed companies in Malaysia. Journal of International Studies, 10(01), 92-99.

Kazemian, S., \& Sanusi, Z. M. (2015). Earnings Management and Ownership Structure. Procedia Economics and Finance, 31, 618-624.

Lee, B. B., \& Choi, B. (2002). Company size, auditor type, and earnings management. Journal of Forensic Accounting, 3, 27-50.

Libby, R., \& Kinney, W. (2000). Does mandated audit communication reduce opportunistic corrections to manage earnings to forecasts? The Accounting Review, 75 (October), 383- 404.

Liberty, S. E., \& Zimmerman, J. L. (1986). Labor Union Contract Negotiations and Accounting Choices. The Accounting Review 61(4), 692-712.

Lobo, G. J., \& Zhou, J. (2006). Did conservatism in financial reporting increase after the SarbanesOxley act? Initial evidence. Accounting Horizons, 20(1), 27-73.

Matsumoto, D. (2002). Management's incentives to avoid negative earnings surprises. The Accounting Review, 77, (3), 483-514.

Mohd Dali, N. R., Mudasir, H. H., \& Abdul Hamid, S. (2008). Performance of Shariah compliance companies in the plantation industry. International Journal of Islamic and Middle Eastern Finance and Management, 1(2), 166-178.

Mohd-Sanusi, Z., Ismail, R., Hudayati, A., \& Harjito, D. (2015). Screening Process of Shariah-Compliant Companies: The Relevance of Financial Risk Management. International Journal of Economics \& Management, 9(1), 177-195.
Oluwo, M. (2007). Strategid Use of Financial Ratio to Prevent Bankruptcy: A Study of Opportunity for Business Enterprise. Capella University, ProQuest Information and Learning Company

Omar, N. (2005). Corporate Governance Rating Initiative in Malaysia. Retrieved from http:// micg.org.my/presentationmaterials.htm

Park, Y. W., \& Shin, H.-H. (2004). Board composition and earnings management in Canada. Journal of Corporate Finance, 10(3), 431-457.

Ronen, J. \& Yaari, V. L. (2008). Earnings Management: Emerging Insights in Theory, Practice, and Research. Springer.

Rosner, R. L. (2003). Earnings manipulation in failing firms. Contemporary Accounting Research, 20(2): 361-408.

Roychowdhury, S. (2006). Earnings management through real activities manipulation. Journal of Accounting and Economics, 42, 335-370.

Schelling, T. C. (1968). Game Theory and the Study of Ethical Systems, Conflict Resolution. 34-44.

Schipper, K. (1989). Commentary on earnings management. Accounting Horizons, 3(4), 91.

Scott, W. (2011). Financial Accounting Theory 6th edition. Prentice Hall

Securities Commission Malaysia. (2013). Islamic Capital Market Statistics. Retrieved Jun 2013, from: http://www.sc.com.my/datastatistics/islamic-capital-market-statistics/

Sun, L., \& Rath, S. (2009). An empirical analysis of earnings management in Australia. International Journal of Human and Social Sciences, 4(14), 1069-1085. 
Sweeney, A. P. (1994). Debt covenant violations and manager's accounting responses. Journal of Accounting and Economics, 17, 281-308.

Ujah, N. U. \& Brusa, J. O. (2011). Earnings management, financial leverage, and cash flow volatility: do economic conditions matter? Available at SSRN: http://ssrn.com/ abstract $=1929550$.

Watts, R. L., \& Zimmerman, J. L. (1986). Positive accounting theory. Englewood Cliff: Prentice Hall 
